\title{
International migration to an economically lagging EU region: case study of Ukraine and Eastern Slovakia
}

\author{
Rossen KOROUTCHEV, Ladislav NOVOTNÝ
}

\begin{abstract}
The research on international migration is usually focused on the most attractive destinations of migrations or areas of origin of migration flows suffering from considerable migration loss. This paper analyses the development and spatial patterns of migration from Ukraine to Slovakia with a special emphasis on Eastern Slovakia, which is employed as a case study of an economically lagging region with significant migration loss. The paper aims to assess if such a lagging region can be an attractive destination for migration from Ukraine, and to what extent migration flows from Ukraine can compensate for its migration loss. By using methods of a statistical analysis based on data from various national and international authorities, field research, and semi-structured interviews, the paper contributes to filling the gap in the research of international migration. Despite the economic lagging behind the western regions, Eastern Slovakia has attracted the majority of migrants from Ukraine to Slovakia. Because the structure of migrants from Ukraine is dominated by well-educated and skilled individuals, who are also culturally close to the domestic population and at the same time well adaptable to a host society, such migration flows are not enough to compensate the massive migration loss of Eastern Slovakia fully but can mitigate its negative consequences including loss of human capital.
\end{abstract}

Keywords: Migration, Slovakia, Ukraine, Eastern Slovakia, Lagging region, Human capital

\section{Introduction}

Ukrainian citizens are one of the largest groups of all third-country nationals living and working in the European Union (EU). Ukrainian migration to the EU is interesting for contemporary migration studies being the largest of all post-USSR migration flows to the EU, as well due to the great variety of occupational and legal statuses and transnational practices. Apart, the Ukrainian migrants form a highly skilled group, which is rapidly adapting to different situations and show a quick integration into the host society (Fedyuk and Kindler 2016).

Since the collapse of the Soviet Union and the Eastern Bloc in general, Ukraine has been struggling with a very problematic economic and social transformation, and geopolitical crises leading to civil disorder and even armed conflicts in recent years, resulting in increasing migration outflow westwards. This particularly concerns Visegrad countries (also referred to as V4 countries: Poland, Czechia, Slovakia, and Hungary) due to their geographic situation and proximity (fig. 1), as well as to their ethnic and historical evolution and ties with Ukraine (Iglicka 2008, Benč 2016, Eröss, Kovály and Tátrai 2016, Jaroszewicz 2018). Ukrainian migration to Central and Eastern Europe became statistically relevant already in the early 1990s but recorded intensive development much later (Fedyuk and Kindler 2016).

Scientific attention to this phenomenon has been recently paid mainly to Hungary, Poland, and Czechia. According to Eröss, Kovály, and Tátrai (2016), migration from Ukraine to Hungary is enhanced by a large Hungarian ethnic minority in Transcarpathia - a region in southwestern Ukraine. In Czechia, the needs of the country's construction sector have enhanced the process of labour immigration of Ukrainians and to the later integration to the host society

DOI: https://doi.org/10.33542/GC2020-2-02 
(Strielkowski 2016). In the case of Poland, it has been recently discussed that the net fiscal position of Ukrainian immigrants in Poland is positive, due to the favourable characteristics of incoming immigrants in terms of age, education, and skills (Kaczmarczyk 2015). Górny (2017) shows Ukrainian migrants who prefer permanent stay in Poland are better educated and working in more attractive sectors of employment in comparison with temporal stayers.

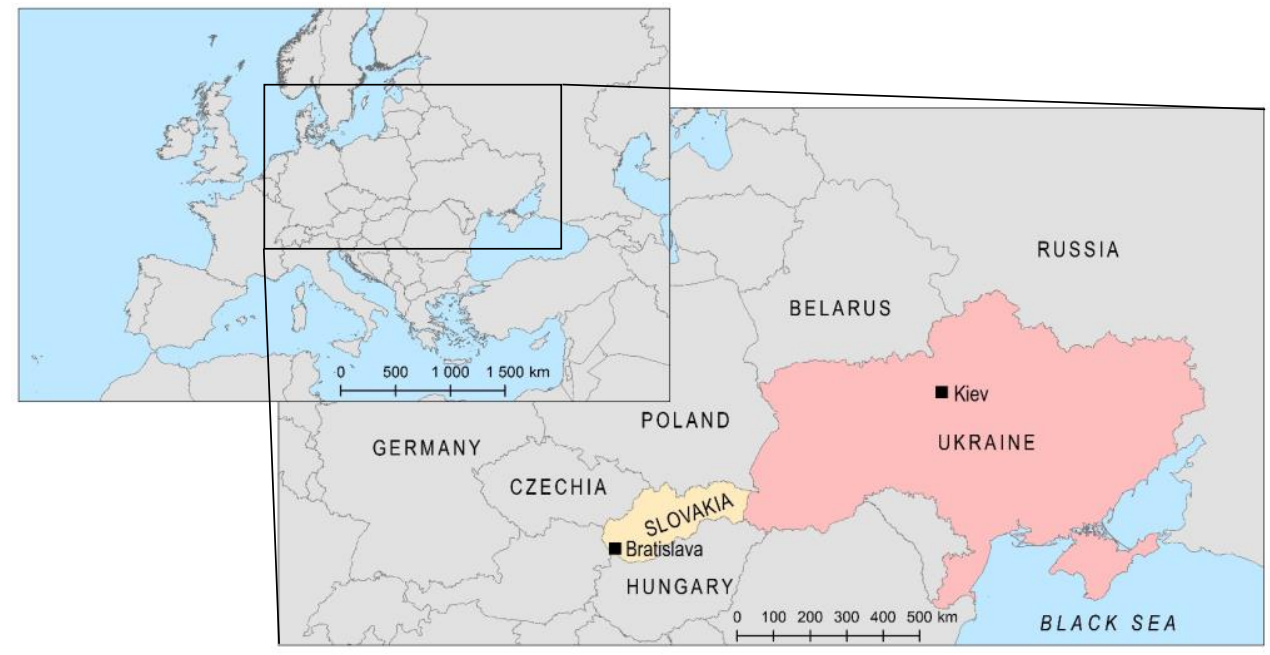

Fig. 1. Ukraine and Slovakia within Europe

Although the number of Ukrainian immigrants in Slovakia is lower compared to its neighbouring countries, there have been ascending trends recorded recently, which are attributed to geographical proximity, and linguistic and cultural similarity. Due to the relatively high level of education and expertise, the Ukrainian immigrants coming to Slovakia are well accepted by society and consequently, they are quickly adapting and integrating. Thus, the phenomenon contributes to the Slovak economy and gives additional merits to the process (Benč 2016). The increasing migration from Ukraine to Slovakia opens a new dimension of the migratory phenomena representing them in a broader sense, which goes beyond the formal change of permanent residence.

Ukraine is the only non-EU and non-Schengen neighbouring country of Slovakia, yet, the exchange across the border is quite intensive. Thousands of people cross the border between the two countries daily.

The relatively low migration flows from Ukraine to Slovakia resulted in less attention paid to this phenomenon in geographical literature. However, its assessment is necessary for obtaining comprehensive knowledge on migration patterns of Ukrainian citizens to the European Union and for understanding changes in the economy and society in Slovakia as well. Because Slovakia is a country with a very low proportion of immigrants on the total population, immigration from Ukraine can be perceived sensitively although the migration flow is smaller in comparison with neighboring countries.

This paper aims to assess the migration of Ukrainian citizens to Slovakia with a special emphasis on the East Slovakia region, which is at the same time recording considerable migration loss due to internal migration to western Slovakia, particularly the Bratislava region (Pregi and Novotný 2019). The presented research is based on statistical data from several sources to obtain the most accurate possible picture of migration patterns. For better understanding, the assessment for Eastern Slovakia is also enriched by the results of semi-structured interviews conducted among Ukrainian migrants with high educational attainment. 


\section{Theoretical and knowledge background}

The very definition of migration is a key issue in migration research. In Slovakia and Ukraine, the migration is officially registered only when migrant reports a change of permanent address to a certain authority. These methods of collecting statistical data are similar to those used in other post-socialist states of Central and Eastern Europe (cf. Jurčová 2005, Ouředníček 2007, Novotný and Pregi 2017, Tyshchuk 2018) and in the context of this study they can be seen as migration in the narrow sense. However, such an approach differs considerably from Western countries and may not capture the real spatial redistribution of the population, and thus changes in the distribution of labor or human capital. When defining international migration, change of permanent address and its reporting to authorities is neither emphasized by Slovak authorities (e.g., MILSAF 2020) nor international institutions operation in Slovakia (e.g., IOM 2020). The UN even states directly in the definition that migration is a change of residence, regardless of the length of stay (UN 2020). Even research from the Central European region does not make the registration of international migration conditional on the permanence of a change of residence, even though there are significant differences between foreigners who are temporary and permanent in the new country (Górny 2017). In this paper, therefore, we also take into account migration in the broader sense, and thus we consider also individuals that change their place of residence, although it may not be a permanent change accompanied by a change of permanent address.

\section{General patterns of international migration from Ukraine.}

Ukrainian migration has roots before the World War I in response to the oppression experienced by the Ukrainian population under the Russian and Austro-Hungarian imperial rule and later influenced by the massive forced relocations of populations during the Soviet-era. However, the most recent Ukrainian migration, mainly related to the labour migration, is due to the social and economic changes that occurred in Ukrainian society after 1991, such as the restructuring of the post-Soviet economy and labour markets, the rise of unemployment, long delays in payments of salaries and wage inflation, among others (Fedyuk and Kindler 2016).

According to projections from the International Organization for Migration (IOM), Ukraine's population will fall by almost $10 \%$ from around 36 million in 2016 to less than 33 million in 2050, with people older than 60 years then accounting for more than $50 \%$ of its population. This represents a substantial loss of human capital for Ukraine in terms of quantity and quality (Malynovska 2016). Moreover, recent studies have emphasized the further losses of educational potential both in absolute and relative indicators, which will inevitably affect the pace of innovation development of the economy as a result of the deterioration of the age and educational structure of the population (Mishchuk 2019).

After the collapse of the USSR in 1991, the political, economic, and social problems were the main push factors for emigration from Ukraine. In recent years, however, changes in the development, in volume, in structure, and spatial patterns of migration flows from Ukraine have been observed. Until 2014, the social and economic situation was the main determinant of Ukrainians' migration. After 2014, new push factors emerged such as political instability and the policy of total mobilisation announced during the early stages of the armed conflict in eastern Ukraine (Gulina, ZOiS 2018).

Due to strong historical ties, Russia is still among the main destinations for migration from Ukraine, although the size of emigration westwards has already surpassed it. The last major wave of migration from Ukraine to Russia took place in 2014 when the Russian annexation of Crimea and the outbreak of armed conflict in eastern Ukraine significantly destabilized security conditions and worsened the economic outlook in Ukraine. The number of Ukrainian citizens who immigrated to Russia increased by more than 0.9 million and went up to 2.5 million 
persons that year. The number of Ukrainian citizens in Russia continued to increase even in the following month but stabilised at 2.6 million after March 2015 (Mukomel 2017).

A sociological survey conducted in 2017 revealed that $29.1 \%$ of Ukrainians are considering emigration due to work or study. Around $53 \%$ of those who have already worked abroad are willing to repeat the experience. By contrast, $43 \%$ is not interested in this kind of migration scenario. $52 \%$ of respondents aged between 18 and 25 years would be willing to leave Ukraine. For the 26-35 age group, this percentage is $42 \%$, and for respondents aged 36-45 years, it is $33 \%$. Of the respondents aged between 46 and 55 years, $23 \%$ would be willing to leave Ukraine. These percentages for the 56-65 and 65+ age groups are only $14 \%$ and less than $9 \%$, respectively (Gulina and Pozniak 2018). The proportion of these percentages is decreasing due to age limitations for a better adaptation to the foreign job market, as well as for the certain proportion of those who wanted to immigrate, have already done it, hence were not included into the survey. Obviously, this is a huge problem and the crucial factor is how the country manages the current political and social situation, what action it takes to stem the outflow of skilled workers, and address the decline in the quality of education and training over the coming years.

Surprisingly, according to the State Statistics Service of Ukraine (SSSU 2018), the country has been recording positive migration balance since 2005. For example, for 2018, the statistical areas with a migration gain were Dnipro (2,552), Ivano-Frankivsk (560), Kyiv (27,142), City of Kyiv (13,942), Lviv (1,886), Odesa (7,696), Chernivtsi (222) and modestly Transcarpathia (84). As can be seen, the net migration is positive where the economic situation is relatively stable and where opportunities exist. However, comparing with the UN data, no positive balance has been observed in Ukraine during the last decade (UNIM 2019) and there is evidence of a mass exodus abroad. These discrepancies between both sources seem to be due to the different methodologies used. Actually, the State Statistics Service does not record migration automatically when the place of residence changed, but only when migration is reported to the State Migration Service by the migrant. Thus, Ukrainians who are permanently or temporarily staying abroad but have not reported it to the Migration Service, are not included in official state statistics on migration. Very similar discrepancies related to migrations of Slovak citizens occur between data of the Statistical Office of the Slovak Republic and data of the statistical offices of the receiving countries (Divinský 2007, Doláková 2016).

Regarding skilled immigrants, the concept of over-qualification has to be taken into account. From theoretical perspectives, these individuals possess higher educational attainment than is required by their job position (Green and Zhu 2010, Valenta and Drbohlav 2018). It is believed that at the level of individual migrants, over-qualification is caused by their aims at the labour market, thus opting for a professional career or just adapt to the best-paid employment (Trevena 2013).

A migrant's success in the labour market of the destination country depends on many different factors such as personality, capabilities, and experience of local culture as well as language skills (Nowotny 2016, Cerna 2016, Sert 2016). The migrant's over-qualification is also influenced by the economy of the host country, the level of unemployment, the effect of the current and past economic crisis, the size of the grey economy, and the effectiveness of the administration and related institutions (Eichhorst et al. 2017, Cangiano 2014).

The Ukrainian migrants represent a typical example of skilled individuals, who have been educated in the ex-USSR educational system (Valenta and Drbohlav 2018). This ensemble is usually regarded as well qualified for the need of the host country's labour market. The Ukrainian qualification has been extensively researched on the case of tertiary-educated Ukrainian migrant workers in the Czech labour market. The most frequent industries are the manufacturing, and health and social work activities, which offer occupations matched to the level of acquired education by $65 \%$ and $90 \%$, respectively. The level of deskilling in the manufacturing industry is similar to that in sales, administrative, and support services, as well as accommodation and food service activities (Valenta and Drbohlav 2018). 


\section{Ukrainian migration in the context of the $E U$}

Currently, both labour and educational migration is seen as an opportunity from the majority of Ukrainians, for a rapid increase of their living standards and entering into the labour markets of the developed, predominantly European, countries (Libanova 2019).

Contemporary migration of Ukrainian nationals to the European Union began in the mid1990s mainly to the countries of Southern Europe as Italy, Spain and Portugal, but also other EU countries with a historical legacy of migration, mainly Germany.

Since 2008, migrants have tended to choose labour markets that have been less affected by the economic crisis, such as the new EU member states in Central Europe, and those that perceive migrant workers from Ukraine favourably (Fedyuk and Kindler 2016). Based on the number of residence permits of non-EU citizens, Ukrainian migrants have by far been the largest group of immigrants in recent years, with employment being the reason for migration in almost $2 / 3$ of cases which is significantly more than for other immigrant groups (Eurostat 2019).

Fedyuk and Kindler (2016) identify six factors influencing the development of Ukrainian nationals to the EU as follows: The first is related to the legacy of Soviet-era spatial mobility, the second to the recession, and increasing political instability in Ukraine. The following one is related to the labour demand in particular sectors of receiving EU countries. The fourth factor is the lack of effective bilateral agreements with receiving countries that would guarantee transfers of pensions and other social benefits. The fifth one is the increase in women's independent labour migration and related gender roles. The sixth stage is related to the political changes in Ukraine since 2013, the Maidan movement, and the military conflict that followed.

Nevertheless, recent research shows the differences between wages in Ukraine and potential remuneration in the country of destination are still the main migration stimuli (Libanova 2019). Additional factors, which stimulate the Ukrainian migration abroad, has revealed that the individuals with more frequent contact with family members abroad are more likely to have migration aspirations, compared to those who have more frequent contacts with friends. This shows the important role of the family's ties on decision making (Van Mol 2018).

Germany is among the most important destinations for Ukrainian migrants, who ranked among the top twenty foreign populations in Germany in 2011 with a total number of 124,293 residence permits (BMI 2011).

Although Greece was not a key destination for Ukrainian migrants, it was among the first EU member states to receive immigrants in the mid-1990s, just after the relaxation of the exit visa regime in Ukraine. According to the 2011 census, 17,008 Ukrainian citizens resided in Greece, making up 2\% of the total non-EU immigrant population (Nikolova 2015).

Concerning Italy, the number of Ukrainian residents has raised almost 20 times, from 12,730 in 2003 up to 226,060 in 2015 . They made up $6 \%$ of all non-EU citizens legally present in Italy, and are the fourth-largest national group (Vianello 2014).

Immigration from Ukraine to Portugal began at the end of the 1990s with a migratory movement that generated one of the largest immigrant groups in Portugal. In 1996, only 71 Ukrainian citizens were registered in Portugal. By 2002 the number had risen to 62,448. In 2014, Ukrainians were the third-largest foreign nationality in the country with 41,091 citizens (Fonseca 2014).

Finally, in the case of Spain, Ukrainians constitute the third-largest community among migrants from Central and Eastern Europe (Kuzio 2012). By 2001 approximately 25,500 Ukrainians were registered in Spanish municipalities. In the following years, the number of Ukrainians registered increased rapidly, reaching 81,132 by 2009 . In recent years the migration of Ukrainians to Spain has slowed down due to the economic crisis and the rapid increase of unemployment. At the beginning of 2014, the total number of Ukraine-born migrants registered in Spain was approximately 85,000 (Fedyuk and Kindler 2016).

Even other EU countries have received a considerable number of Ukrainian immigrants. For example, in 2018, the number of first residence permits for Ukrainians was 6,041 in Lithuania, 2,292 in Latvia, and 1,649 in Estonia. Demark granted 3,723 permits for Ukrainians, Bulgaria 1,095, etc. (Eurostat 2019). 


\section{Ukrainian migration to the Visegrad countries}

Central European countries with language close or familiar to Ukrainian (mainly V4 countries: Poland, Czechia, Slovakia, as well as Hungary for Ukrainian citizens with Hungarian ethnic origin) have recently become favoured for migrants from Ukraine. The rapid increase of Ukrainian immigrants was recorded particularly in Poland (i.e., three times more in 2017 compared to 2012; Jaroszewicz 2018), but other Visegrad countries recorded similar trends. Most of them are emigrating due to the low wages in Ukraine, but apart, there are other reasons such as an intent to escape from the control of traditional family structures and the mandatory military service. Increasing migration flows to Visegrad countries contrast with long-term migration declines of many regions in these countries, especially in their eastern parts (Eurostat 2020d), even though it is often due to intra-national migration. Moreover, these countries are rather negatively affected by the brain-drain within the EU (Cavallini et al. 2018). Hence, the migration from Ukraine has the potential to compensate for the loss of human capital in V4 countries and their regions.

Unlike other V4 countries, immigration to Hungary has a strong ethnic background. It is a non-Slavic country based on which it could be expected to be less attractive for Ukrainian (or Russian) - ethnic Slavic migrants (Eröss, Kovály and Tátrai 2016). However, it attracts ethnic Hungarians constituting a significant ethnic minority in south-western Ukraine (Transcarpathia). They account for $70 \%$ of the total migration flow from Ukraine to Hungary (Kincses 2015).

Ukrainian migration to V4 countries, and especially to Poland, is mainly temporary and of a circular type (Brunarska 2016). Immigration to Poland is enhanced by a liberal procedure for legalising residence and work (for short periods) and a large migration network. By the end of December 2017, the number of Ukrainian citizens who had been given a declaration of intent was 517,000 , whereas 208,000 of them had a work permit. To this number should be added the group of around 100,000 Ukrainian citizens who are permanent residents in Poland and do not need a work permit. In total, this gives around 900,000 migrants from Ukraine in Poland at the end of 2017 (Jaroszewicz 2018, Sokołowicz 2018) making it a V4 country with by far the largest migration stock of Ukrainian nationals and one of largest worldwide (Fedyuk and Kindler 2016).

Ukrainians are the largest group among migrants in the Czech Republic. Ukrainian migration grew rapidly before 2008 but stabilized after the Global economic crisis as it was primarily economic migration. Ukrainian immigration to the Czech Republic was for many years seen as temporary labour migration dominated by men. However, nowadays almost half of the immigrants are women. Ukrainians are no longer temporary guest workers in the Czech Republic as they have become integrated into the country's society (Benč 2016).

Finally, comparative statistics concerning the residence permits for Ukrainian citizens in the Visegrad countries are given in Tab. 1. It shows considerable differences among the countries but confirms the flows from Ukraine to the V4 countries have been massive recently. The absence of data for Hungary in 2014 and 2013 because the Ukrainians were not within the first three largest groups of immigrants to the country, hence the data on them are not contained in the Eurostat $(2014,2015)$ statistics.

Tab. 1. First residence permits for Ukrainians issued in the Visegrad countries (2013 - 2018)

\begin{tabular}{ccccc}
\hline Year & Poland & Czechia & Slovakia & Hungary \\
\hline 2018 & 413,449 & 26,979 & 10,584 & 21,793 \\
2017 & 585,439 & 18,877 & 4,268 & 7,808 \\
2016 & 512,552 & 24,233 & 3,016 & 2,375 \\
2015 & 430,081 & 23,207 & 3,340 & 1,686 \\
2014 & 247,397 & 12,867 & 1,592 & $\mathrm{~N} / \mathrm{A}$ \\
2013 & 171,769 & 18,622 & 1,040 & $\mathrm{~N} / \mathrm{A}$ \\
\hline
\end{tabular}

Data sources: Eurostat (2014, 2015, 2016, 2017, 2018a, 2019) 
Despite the fact that the salaries the immigrants earn in the V4 countries are small compared to western EU countries, massive and predominantly labour motivated migration from Ukraine shows the low living costs compensate this differences and allow other migration pull factors to have a greater effect, and make regular remittances flows to Ukraine possible (Sokołowicz 2018).

\section{Methods}

The primary evaluation of migration as well as the economic performance of Eastern Slovakia is based on a statistical analysis of data from several sources. Eastern Slovakia as a territorial unit can be perceived from various aspects, and therefore its delimitation also varies. To avoid ambiguity and obtain interregional comparability of the results, we considered Eastern Slovakia within its borders as NUTS2 (fig. 3), which includes the territory of two selfgoverning regions: Košice and Prešov. The region covers an area of over 17,500 km² (32\% of Slovakia) with 1.63 million inhabitants (30\% of Slovakia as of 2019).

Anonymised annual data on individual cross-border migrations to Slovakia provided by the Statistical Office of the Slovak Republic (SOSR) for the period 1996 - 2018 (SOSR 2019a) enabled detailed analysis of the spatial pattern of migration and its development over time covering the period of economic decline during the early phase of the post-socialist transformation and rapid economic growth during the mid-2000s. This growth followed substantial economic reforms at the turn of the millennium and lasted until the global economic crisis, which hit Slovakia in 2008. The following period has been featured by modest but continuous growth which is likely to be terminated by global economic decline resulting from the pandemic spread of Covid-19 worldwide. Besides, the pandemic has returned Ukrainian migrant workers back home, thus depriving the Slovak economy of some specific working force (Semchuk 2020).

The data contain information about the year of migration, country of origin, country of destination, and the community of destination. Besides the assessment of immigration at the level of individual communities, aggregation of data enabled evaluation of migration separately for Eastern Slovakia.

As the records of the SOSR do not cover all forms of migration in the wider sense, the data provided by other authorities were used to obtain the most accurate image possible of the current numbers of Ukrainian citizens living in Slovakia. This includes the Slovak Ministry of Internal Affairs to analyse the evolution of the residence permits to foreigners in Slovakia (2015-2018), the Foreigner Police Office to study the number of Ukrainian citizens immigrating to Slovakia (2018), the State Statistics Committee of Ukraine to research the migration flows of Ukrainians to Poland (2012-2017), as well as Eurostat statistical data to analyse the demographic evolution of Eastern Slovakia (2017). This all was discussed with data from relevant literature as well.

Assessment of economic, demographic, and social characteristics in Eastern Slovakia (as well as the evolution of the Ukrainian citizens there) in comparison with other NUTS2 in the country was conducted based on data from the SOSR, and its databases StatDat (SOSR 2019b) and DATAcube (SOSR 2020a, b).

For international comparisons of Slovakia and Eastern Slovakia with neighbouring countries including NUTS2s regional level, the data from the World Bank (2020), and Eurostat (2020a, b, c) were used.

The field research was conducted in Transcarpatia (Ukraine) which shares some common history with Slovakia. This region was part of Czechoslovakia before the World War II. As a consequence of the shift of the border, many families were divided between the two countries: the Soviet Union and Czechoslovakia at that time, and recently between Ukraine and Slovakia. The main purpose of the fieldwork was to identify how potential work in Slovakia is promoted by recruitment agencies in comparison with Poland, Czechia, or Hungary. 
Several semi-structured interviews were also conducted to understand the main challenges of the Ukrainian society and the origins of the massive emigration as well as future perspectives of immigrants or expatriates from Ukraine in Eastern Slovakia. These surveys were performed with 10 Ukrainian skilled immigrants working in Košice, six of them researching on their $\mathrm{PhD}$ thesis or postdoctoral qualification at the Pavol Jozef Šafárik University in Košice and the rest, originating from Transcarpathia, being currently studying or working in Eastern Slovakia. The emphasis was on the selection of highly skilled immigrants from the academic surrounding, thus ensuring high quality of expertise of the participating subjects.

\section{Economic performance and migration in Eastern Slovakia}

After the adoption of the reforms by a predominantly right-wing government at the turn of centuries, Slovakia experienced temporal economic decline followed by significant growth. Slovakia's performance started to catch up with Western European economies. The inflow of foreign direct investments per capita considerably exceeded neighbouring countries (Švecová and Rajčáková 2013). Thus, referring to the economic boom in the country south of the Tatra Mountains, Slovakia became labelled as Tatra Tiger (Grančay and Grančay 2017). By economic performance, the country came closer to the Czech Republic and gained a lead over Poland and Hungary by the late 2000s. Despite slight economic growth, Ukraine lagged significantly behind the V4 countries and the gap between Slovakia and Ukraine has widened (fig. 2). Although the growth in the performance of the Tatra Tiger compared to other V4 countries slowed after the global economic crisis in 2008, the gap between Slovakia and Ukraine has increased (Grančay and Grančay 2017, World Bank 2020).

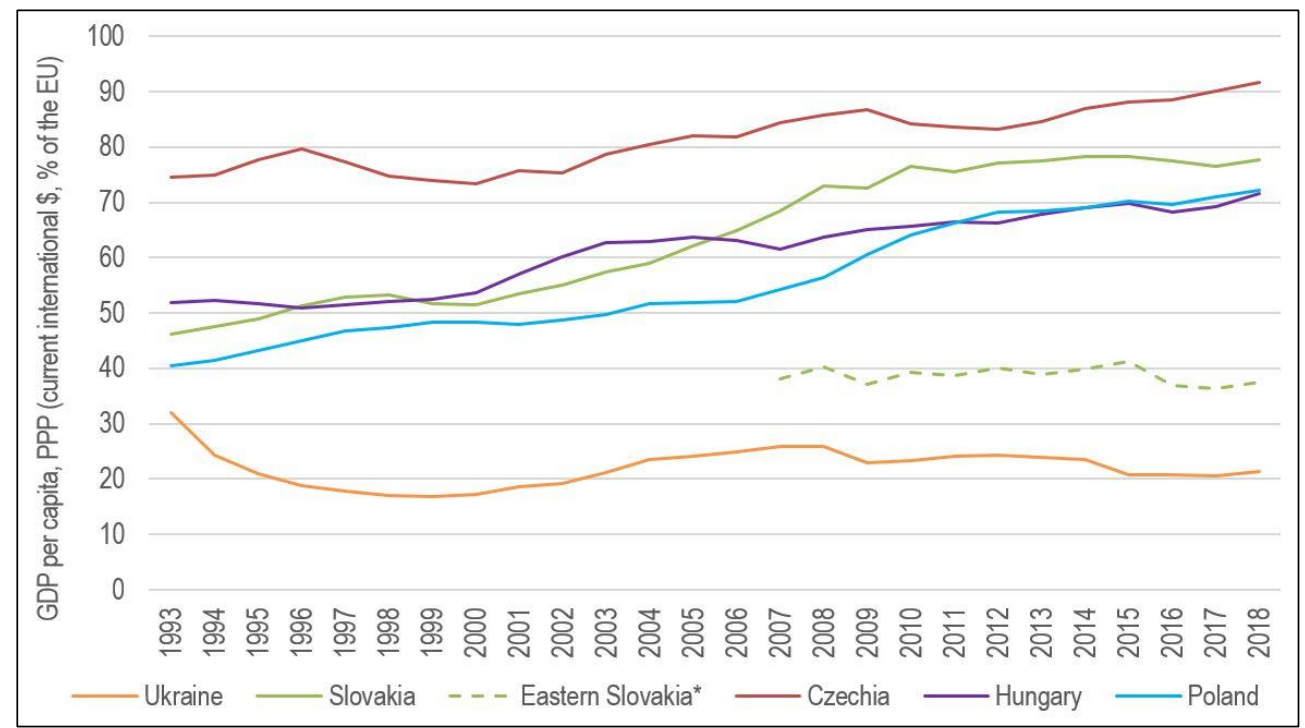

Fig. 2. Development of economic performance of Visegrad countries and Ukraine expressed as GDP per capita PPP percentage of the EU. Based on data from World Bank (2020), *NUTS2 Eastern Slovakia development based on data from Eurostat (2020c)

However, Slovakia suffers from huge regional disparities (Švecová and Rajčáková 2013) with a specific pattern dividing the country into developed western and north-western Slovakia and lagging southern and south-eastern Slovakia. Although Košice is among the major economic hubs in the country, it lags significantly behind Bratislava and the south and southeastern part of Slovakia is featured by considerable concentration of peripheral areas (Halás 2008, 2014), (fig. 3). 


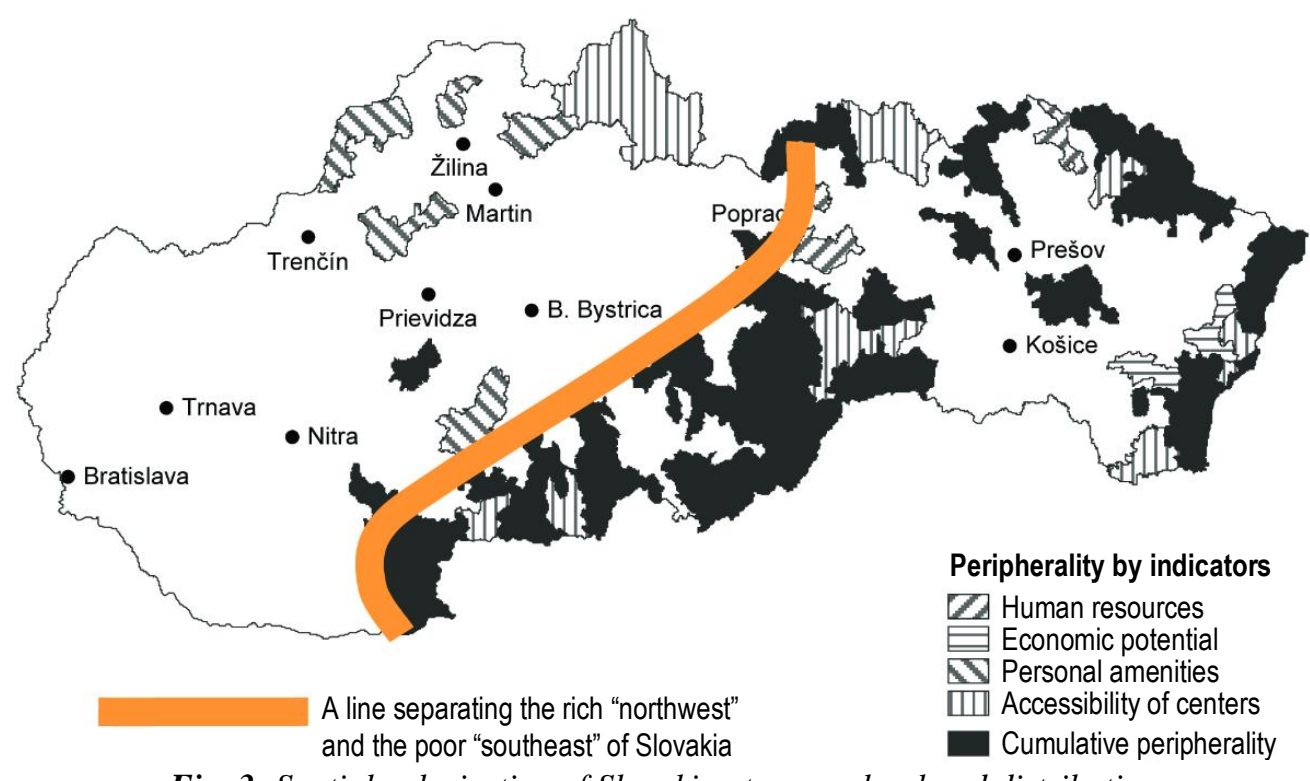

Fig. 3: Spatial polarisation of Slovakia at macro-level and distribution of peripheries as indicated by Halás (2008, 2014)

Compared to the national average and other NUTS 2 in the country, Eastern Slovakia shows the weakest economic performance (tab. 2). However, the national average seems to be deformed mainly by the Bratislava region, which shows average earnings of almost $50 \%$ and GDP PPS per capita even about 300\% higher than other NUTS2. The variability among the three remaining NUTS2 in Slovakia is rather insignificant. On the other hand, the unemployment rate reaches similar values in the Bratislava region and the Western Slovakia region but rises gradually eastwards. Generally, the region of the capital contributes to the overall image of regional economic differences in Slovakia, while the variability among remaining NUT2 is not that significant in many indicators. At the same time, Eastern Slovakia is featured by the lowest economic performance within the country. This results in continuously increasing internal migration loss of Eastern Slovakia in favour of western regions and particularly Bratislava (fig. 4) and considerable outflow of human capital (Novotný 2019, Pregi and Novotný 2019) from the region. The only exception is the Košice functional urban region which has a positive migration balance of young people and university graduates, despite general migration loss (Novotný, Pregi and Kmec 2018).

Tab. 2. Regional variability of chosen economic indicators in Slovakia (values for 2018)

\begin{tabular}{lcccc}
\hline NUTS 1 / NUTS 2 & $\begin{array}{c}\text { Gross household } \\
\text { income (€/month) }\end{array}$ & $\begin{array}{l}\text { Earnings of employees } \\
(€ / \text { month) }\end{array}$ & $\begin{array}{l}\text { Registered } \\
\text { unemployment rate }(\%)\end{array}$ & $\begin{array}{c}\text { gross domestic product } \\
\text { (PPS per inhab.; \% EU27) }\end{array}$ \\
\hline Slovakia & 810.3 & 1171 & 5.0 & 74 \\
Bratislava region & 998.6 & 1532 & 2.8 & 173 \\
Western Slovakia & 827.7 & 1078 & 2.9 & 67 \\
Central Slovakia & 764.8 & 1058 & 5.3 & 59 \\
Eastern Slovakia & 752.5 & 1022 & 7.9 & 53 \\
\hline
\end{tabular}

Data sources: Eurostat (2020a, b), SOSR (2019b, 2020a, b) 


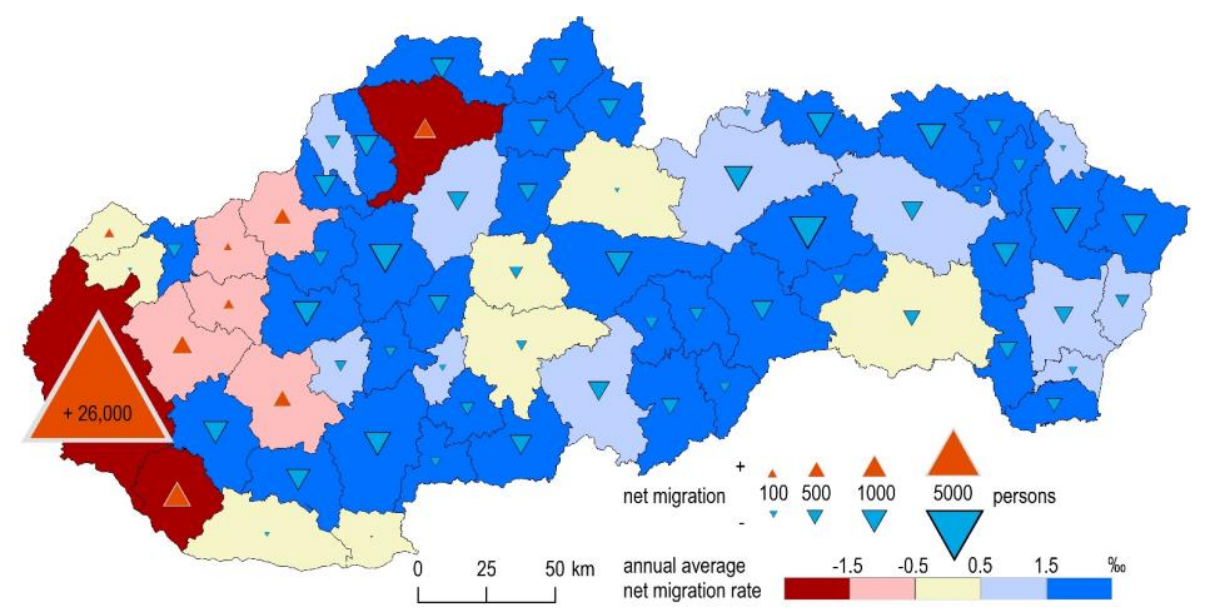

Fig. 4: Intra-national migration in the functional urban regions in Slovakia over the period 2012-2016; Based on Novotny (2019)

Even though Eastern Slovakia lags behind other NUTS2 in Slovakia when considering GDP per capita (PPS), it performs significantly better than the national average for Ukraine (fig. 2). Also, Eastern Slovakia is bordering with Polish and Hungarian NUTS2 with similar (Malopolskie in Poland) or even considerably lower performance (Podkarpackie in Poland, and Borsod-Abaúj-Zemplen and Szaboks-Szatmár-Bereg in Hungary).

This is important because it indirectly indicates that Eastern Slovakia could be more attractive for Ukrainians, than Polish or Hungarian regions bordering with Ukraine. Actually, Eastern Slovakia has recently recorded an important increase in the number of Ukrainian immigrants, who are involved in the sectors of industry and services. In addition, as will be discussed in the next section, a high percentage of legally working Ukrainians are specialists with university degrees, followed by those with secondary education. This makes the Ukrainian immigrants attractive in the labour market, thus importing valuable knowledge, experience, and capacity for easy adaptation due to common historical and cultural roots.

\section{Migration from Ukraine to Slovakia}

Slovakia has the lowest proportion of immigrants (non-national citizens) in the total population of all of the European Union countries (fig. 5). The share of immigrants in Slovakia is 1.3 which is considerably smaller even than in other V4 countries (Eurostat 2018b).

Statistical Office of the Slovak Republic recorded 117,475 immigrations to Slovakia over the period $1996-2018$ and 5,515 of them were from Ukraine. However, the number of immigrants is higher and slightly increasing when considered based on residence permit (fig. 6). Development from 2014, when the Ministry of Internal Affairs of Slovakia (MIAS) started to publish annual data by nationality shows the rapid growth of numbers of all third countries, and particularly Ukrainian nationals. The number of residence permits granted to Ukrainians outnumbered the number for all other third-country nationals in 2019. Ukrainian nationals with 23,566 permits were followed by Serbian $(6,233)$, Vietnamese $(2,849)$ and Russian $(2,115)$ nationals (MIAS 2009-2020).

Since Slovakia accessed the Schengen area in 2008 (in fact the official accession was on December 21, 2007), the number of identified illegal immigrants to the country has been fluctuating but generally growing. The proportion of Ukrainian immigrants was insignificant in 2008 but since that year it has been the largest source of illegal immigration. With the exception in 2019, the number of illegal migrants from Ukraine has also been continuously growing and its development became decisive for the overall development of illegal migration to Slovakia in 2016 (fig. 7). 


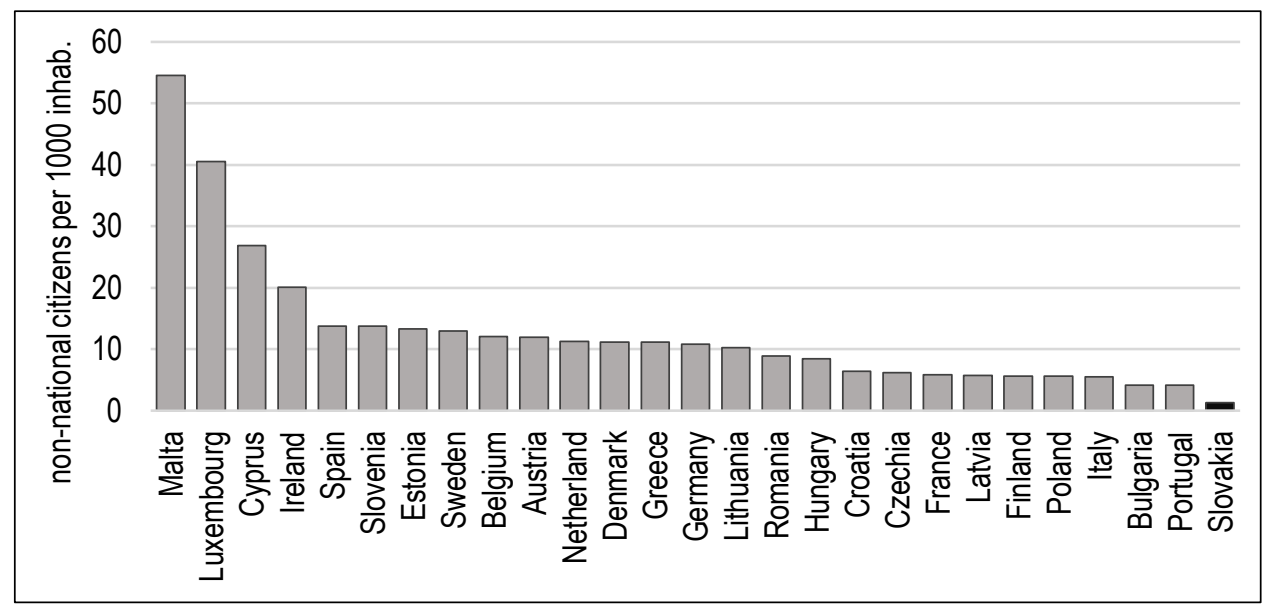

Fig. 5. Number of non-national citizens per 1000 inhabitants in the EU countries (2018); Source: Eurostat (2018b)

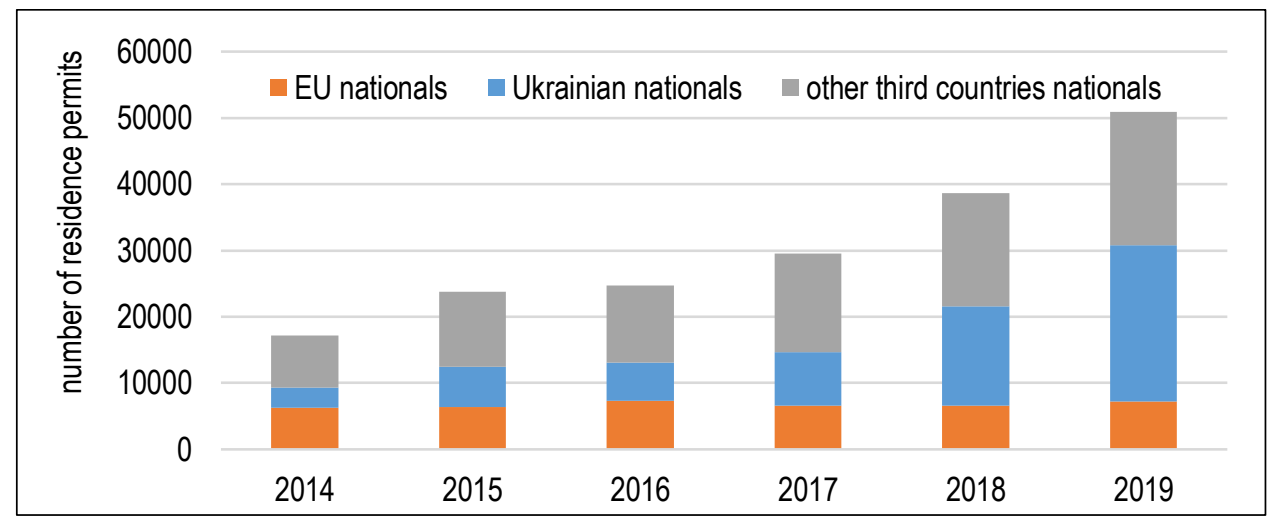

Fig. 6. Total number of valid residence permits granted to EU, Ukrinian and other third countries nationals during annually in the 2015-2018 period, including temporary and permanent residences; Source: MIAS (2009-2020)

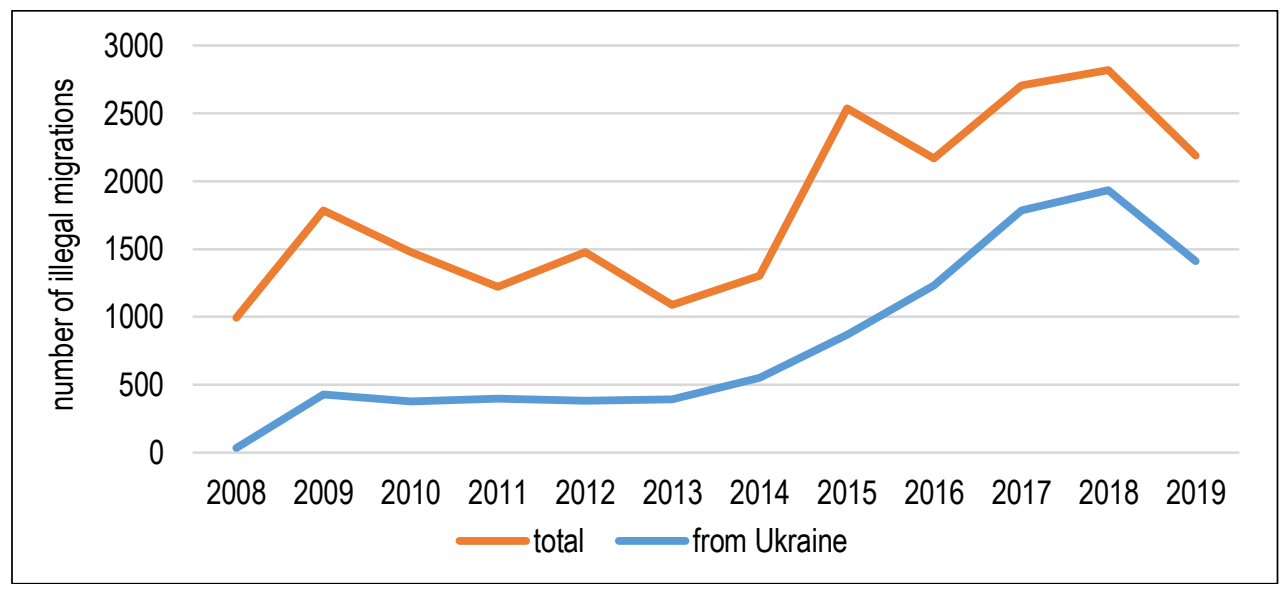

Fig. 7. Development of the illegal immigration to Slovakia since its accession to the Schengen area; Based on data from MIAS (2020) 
The same tendency is observed in the number of Ukrainian citizens migrating to Slovakia. The latest statistics provided by the Foreigner's Police office (MIAS 2009-2020) report a total of 65,381 third-country-nationals residing in Slovakia by 31 December 2018, which increased to 85,827 by the end of 2019 ; while the number of Ukrainian nationals in the country in 2018 was 24,913 and increased to 38,307 by the end of 2019 . These numbers are considerably higher than the data reported by the Statistical Office of the Slovak Republic (SOSR 2019). However, data by SOSR are detailed enough to indicate general tendencies of migration as well as features of its spatial patterns. Despite clear differences in total immigration to Slovakia and for migration from Ukraine separately, some common patterns are identifiable to distinguish key development phases from the late 1990s (fig. 8).

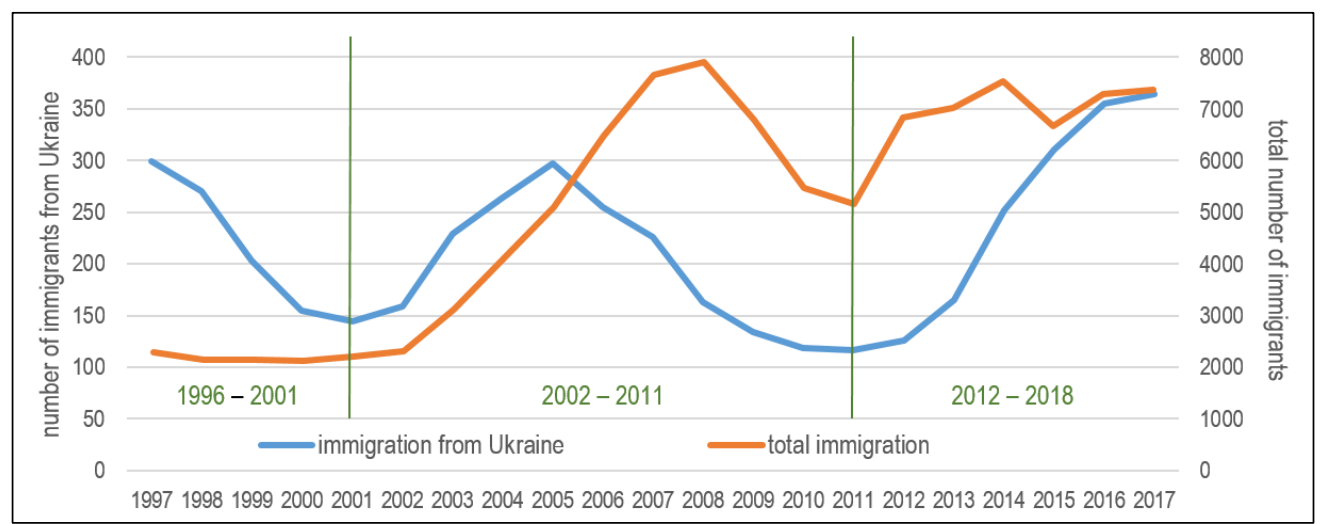

Fig. 8. Development of the annual number of immigrants to Slovakia and immigrants from Ukraine to Slovakia separately (1996-2018; three-year moving weighted average); Based on data from SOSR (2019a)

The economic decline in Slovakia in the late 1990s led to a decrease in the number of migrants from Ukraine, while the total annual numbers of migrants were nearing historical lows during this period. A turning point in this development occurs around 2001. Rapid economic growth is followed by a significant increase in the number of immigrants. Although the number of migrants from Ukraine started to decrease again in the mid-2000s, the growth of the total number of immigrants had not peaked until 2008, when Slovakia was also significantly affected by the global economic crisis. The subsequent decline in the number of immigrants was reversed in 2011. Although the total annual numbers of immigrants have not reached the 2008's record till the end of the period under consideration, the numbers of migrants from Ukraine have been reaching historical highs since the mid-2010s. This also indicates an increasing contribution of Ukrainian citizens to the total immigration balance of Slovakia.

Despite the increasing numbers of migrants from Ukraine, according to the authors' field trips and interviews, Slovakia does not seems to be a very attractive immigration destination for Ukrainians, although the salary levels are similar to Poland. This is probably due to the economic downturn and high unemployment in Slovakia in the near past (Liptáková 2010). Most of the job offers in Ukraine for working abroad are for work in the manufacturing and construction sectors, with an average pay of around $€ 2.5-€ 3.5$ per hour net (Eurabota 2019a). Similar is the situation in Slovakia, where the Ukrainians are usually hired in the car manufacturing factories and subcontractors located predominantly in Western Slovakia (Eurabota 2019b).

This was confirmed during the fieldwork in Transcarpathia. It was observed that in small towns, like Khust, there are many work/visa agencies for employment abroad. Most of them arrange a working visa for around $€ 100$. Almost all jobs abroad pay around $€ 2.5$ to $€ 3.5$ per hour, so basically, to save money a long working day is often practiced. 
In general, the behaviour of the Slovaks towards the Ukrainian migrants is perceived as very good and positive, although certain changes during the current international migration increase have been recently observed (Benč 2016), including violations of Ukrainian workers' labour rights are a serious problem in Slovakia (Chudžíková 2018).

Ukrainian nationals are mostly employed through work permits in the transportation sector (677) and in health care (404). In addition, permits for Ukrainian nationals were most often associated with small businesses (161), construction (107), and restaurants (62). Companies from various sectors are looking to hire Ukrainians. On the other hand, agencies able to recruit Ukrainian workers have also appeared (Eurabota 2019a,b).

The structure of Ukrainian citizens legally employed in Slovakia is favourable when considering expertise and specialization. Out of 17,382 Ukrainian citizens in February 2020, skilled workers and craftsmen constituted about $20 \%$ which is considerably more than an average for all third-countries nationals. Significant numbers of Ukrainian nationals are employed as specialists, technicians and professionals, administrative staff, service and trade workers, and skilled workers in agriculture, forestry, and fishing (categories defined by OLSAF) (OLSAF 2020). Nevertheless, comparing the current structure of employees with 2015 (Benč 2016) shows that increasing numbers of Ukrainian nationals employed in Slovakia leads to the increase in the proportion of low-skilled workers at the expense of high-skilled workers and specialists. This seems to be in line with the shortage of mostly cheap labour in the expanding industrial production in Slovakia. However, the prevailing low skill profile of the migration inflow is a concern for the country's perspective as the attention in supporting higher-skilled migration is insufficient. The interest in supporting higher-skilled migration remains low at the policy level and the country lacks a longterm vision of strategic migration policy (Štefánik 2018).

Since 2018, OLSAF is publishing occupations with labour supply shortage during the previous calendar year, in regions where the registered unemployment rate did not exceed 5\%. In 2018, the most frequent occupations were from the category of plant and machine operators and assemblers. In each region, medical professionals, especially doctors, are demanded as well. Further modifications facilitating the recruitment process of third-country nationals were approved by the government in November 2018, thus the employment of third-country nationals is supported via Strategic Service Centres (Štefánik 2018).

Data by OLSAF from 2020 also show favourable educational structure of Ukrainian employees. They constitute 59\% of all third-country nationals legally employed in Slovakia (in February 2020) but almost $80 \%$ of these with the master (or equivalent) degree and $70 \%$ of these with $\mathrm{PhD}$. On the other hand, they constitute only $25 \%$ of these with only elementary educational attainment.

It is very likely that an analogous mismatch of tertiary-educated Ukrainian migrant workers, similar to that found in Czechia by Valenta and Drbohlav (2018) also exists in the Slovak labour market, although such analysis goes beyond the scope of the present publication.

\section{Migration of Ukrainian nationals to Eastern Slovakia}

Most cross-border migrations to Slovakia go to its western, more economically developed part with an understandable dominance of Bratislava. The total number of international migrants to Bratislava as registered by the SOSR exceeded 20,000 and contributed by over $17 \%$ to total international migration to Slovakia during the period 1996 - 2018. Košice, the second-largest city in Slovakia and major city of Eastern Slovakia, reached only less than $5 \%$ proportion with fewer than 5,500 migrants. However, migrations from Ukraine shows a substantially different spatial pattern. Although Bratislava recorded the largest number of migrants from Ukraine, their number in Košice was only slightly lower. These cities were followed by the smaller towns of Sobrance and Michalovce located in the proximity of the Ukrainian border (fig. 9). A specific situation appears in border-town Sobrance where almost 500 immigrants from Ukraine contributed to stabilisation of population size in the town with only about 6,000 inhabitants. 
After the World War II, the border between Czechoslovakia and the Soviet Union was shifted westwards at the expense of Slovakia so that the Ukrainian border town of Uzhhorod got a direct railway connection with the rest of the Soviet network. This way Slovakia lost town Chop with an important railway hub and several adjacent villages in the south-eastern tip, leaving the number of families divided by a strictly guided border. Persisting family ties may be one of the reasons why localities in the south-east of Slovakia appear to be more attractive to migrants from Ukraine than in the north-east (fig. 9).

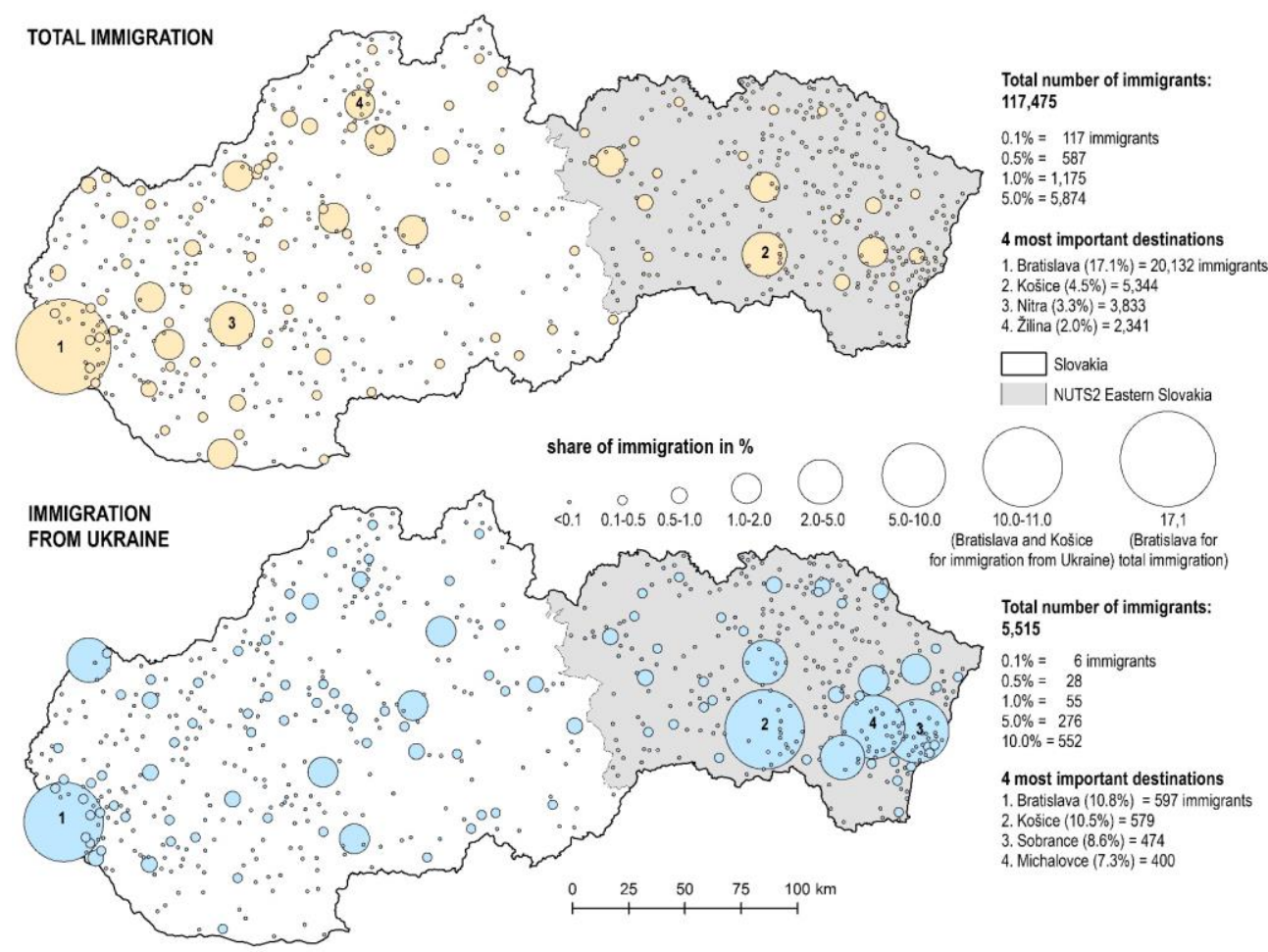

Fig. 9. Spatial distribution of international migrations to Slovakia expressed as a proportion of all migrations to Slovakia at the level of communities during the period 1996 - 2018;

Based on data from SOSR (2019a)

NUTS2 Eastern Slovakia accounted for only less than one-fifth of the total number of cross-border migrations to Slovakia, but more than half of migrations from Ukraine went to this region. During the phase of the rapid economic growth of the country, the attractiveness of Eastern Slovakia apparently decreased what is reflected by a much lower contribution of this region to the total immigration to Slovakia. However, during the period $2012-2018$, Eastern Slovakia accounted for almost one-quarter of total migrations to Slovakia and almost two-thirds of migrations from Ukraine (tab. 3).

Tab. 3. Number of international migrants to Eastern Slovakia over the 1996 - 2018 period

\begin{tabular}{lrrrrrrrr}
\hline & \multicolumn{2}{c}{$1996-2018$} & \multicolumn{2}{c}{$1996-2001$} & \multicolumn{2}{c}{$2001-2011$} & \multicolumn{2}{c}{$2012-2018$} \\
& total & $\%^{*}$ & total & $\%^{*}$ & total & $\%^{*}$ & \multicolumn{1}{c}{ total } & $\%^{*}$ \\
\hline all immigrants & 21,531 & 18.3 & 2,356 & 17.9 & 7,406 & 13.7 & 11,769 & 23.5 \\
immigrants from Ukraine & 2,858 & 51.8 & 696 & 51.1 & 804 & 39.4 & 1,358 & 64.4 \\
\hline
\end{tabular}

${ }^{*}$ Proportion of the total international immigration to Slovakia. Based on data from SOSR (2019a) 
Similar tendencies are observed when the number of valid residence permits for thirdcountry nationals is considered. It reached 13,214 in December 2018 with an ascending trend when compared to previous years (MIAS 2009-2020).

Although the observed behaviour is similar, the reasons for the growth in the total number of international immigrants to Eastern Slovakia and the number of migrants from Ukraine may differ. Beside massive internal-migration loss, Eastern Slovakia has suffered the largest losses among Slovak regions when international emigration is considered. International emigration culminated after Slovakia's accession to the EU, but the trend is continuous. However, recent years have shown an increasing trend of re-emigration from Western Europe back to Slovakia (Homola 2019). This is particularly related to the United Kingdom, where, with significant contribution of the Brexit's referendum results, the registered number of Slovak citizens decreased from 92,000 by the end of 2016 to 72,000 by the end of 2018 (Janko 2019). The Slovak statistical office does not register many citizens living abroad for a long time or permanently as emigrants (unless they notify the Slovak authorities of a change of permanent residence) (Divinský 2007), and thus does not register their return migration. However, Doláková (2016) points out that often whole families with children born abroad and/or with one of the partners who are not Slovak citizens return from abroad and so contribute to the positive cross-border migration balance. Thus, the increased number and share of international migration to Eastern Slovakia may be partly due to higher emigration from this territory in the past.

However, the re-emigration itself cannot explain the increased migration to Eastern Slovakia from Ukraine. A possible explanation stems from analogy with V4 and western countries. Although the salaries in Eastern Slovakia are small compared to Western Slovakia and particularly Bratislava, the difference is at least partly compensated by lower living costs. It allows regular remittances flows towards Ukraine and migrants to allow other benefits of the regions (spatial and cultural proximity, family ties, etc.). Moreover, universities in Slovakia suffer from an outflow of potential students to Czechia and the Western countries, and at the same time strive to internationalise their studies. Several universities in the Eastern Slovak cities of Košice and Prešov are taking the advantage of the spatial, but also cultural and linguistic proximity of Ukraine and are increasingly attracting Ukrainian students (Nejedlý 2019).

The number of university students who are Ukrainian nationals has been growing significantly, particularly after 2011. In 2016, 1,258 Ukrainian students studied in Slovakia and 723 of them in Eastern Slovakia. The survey performed with Ukrainian students in Eastern Slovakia within the ZIP project 'Zipping and Innovating the Development Planning of the CrossBorder SK-UA territory' (Onufrák 2017) reveals important aspects of this phenomena. According to these surveys, Slovakia was selected as a country of destination due to the proximity to the homeland (31\%), existing links such as family, friends (24\%), similar language (15\%), historic, cultural, and religious links (6.7\%) and other reasons (22\%). Regarding their decision where to move if they have to choose it again, $62 \%$ stated Slovakia, $11 \%$ Czechia, $6 \%$ Poland and the rest - other countries. 54\% reported that they would not like to return to Ukraine, while the rest will do it under specific conditions. Only 13\% reported their willingness to return back to Ukraine (Onufrák 2017).

In order to see how the above trends are in Eastern Slovakia, we performed surveys with 10 highly skilled Ukrainian immigrants, the majority of them are students or academic researchers living in Košice. The surveys indicated similar migration trends and attitudes, to those cited above, i.e. the intention to look for job opportunities abroad instead to return to Ukraine.

The interviews emphasized the important role of geographic, cultural, and linguistic proximity of Slovakia to Ukraine when making the migration decision, although the majority of them came from Central and Eastern Ukraine. All of the participants feel well appreciated at their work and seem integrated despite not speaking Slovak properly. The majority of them states that probably they will not return to Ukraine after the end of their scheduled stay in Slovakia and will try to extend their stay in Slovakia or look for another job opportunities in 
surrounding Central European countries such as Poland, Hungary, Czechia, or Germany, either by applying for similar competitive positions, either going to the industry after completion of the doctoral thesis or the postdoc positions. Similar attitudes have been expressed also by Ukrainian immigrants outside the academic community, and their attitudes were based on the limited job opportunities in their home regions and country.

\section{Conclusions}

As a destination for international migration, Slovakia lags behind its Central European neighbours. Therefore, it is natural that even in international research much less attention is paid to its performance. At the same time, Slovakia is a country with significant regional disparities stimulating the polarization of domestic migration flows. In particular, Eastern Slovakia is losing population and human capital at the expense of western regions, especially Bratislava. Eastern Slovakia is also a source area for significant migration flows to Western European countries. However, the source of much more massive migration flows to the west is the eastern neighbour of Slovakia - Ukraine, which according to international statistics suffers from massive migration loss of population and its citizens are becoming a major immigration group from third countries in almost all EU countries.

Despite lagging behind the other Visegrad countries, the volume of migration from Ukraine to Slovakia has increased significantly over the last decade due to their closeness, similar culture, successful adaptation of the immigrants, and the opportunities, which Slovakia offers as an EU country with growing economic lead over Ukraine. Spatial patterns of migration show that despite an economic lagging behind the rest of the country, Eastern Slovakia is the most attractive destination for migration from Ukraine among NUTS2 in Slovakia. Almost 2/3 of all migrations from this country has led to Eastern Slovakia recently. Moreover, this share has a growing tendency in the medium term. In this case, it seems that the geographical proximity and perhaps also family ties compensate for lower wages or a smaller choice of job offers compared to Western Slovakia. In addition, the Eastern Slovak universities have become a significant stimulus for migration from Ukraine. Such universities actively attract Ukrainian students and postdoctoral researchers. A survey conducted at Pavol Jozef Šafárik University in Košice suggests that even after the end of the contract, a significant number of these experts are interested in remaining in the region.

Eastern Slovakia has lost more than 30,000 inhabitants due to predominantly domestic migration since the early 1990s. Hundreds of immigrants from Ukraine are far from being able to fully compensate for these losses. However, they show that greater openness to immigration from Ukraine can help mitigate the negative effects of depopulation in the region. Immigrants from Ukraine are featured by favourable professional and educational structure for the destination region. Thus, it is a chance to gain brains for a region suffering from brain drain, and so to maintain human capital as a factor necessary for the further economic development of Eastern Slovakia.

\section{References}

BENČ, V. 2016: Growing migration of Ukrainians into Slovakia: new migration patterns as a result of the unstable situation in Ukraine. In Drbohlav. D., Jaroszweicz, M. eds. Ukrainian Migration in Times of Crisis: Forced and Labour Mobility. Prague (Charles University, Faculty of Science), 130-167.

BMI 2011: Migration und Integration. Aufenthaltsrecht, Migrations- und Integrationspolitik in Deutschland. Berlin (BMI - Federal Ministry of the Interior of Germany).

BRUNARSKA, Z., KINDLER, M., SZULECKA, M., TORUŃCZYK-RUIZ, S. 2016: Ukrainian Migration to Poland: A "Local" Mobility? In Fedyuk, O. and Kindler, M. eds. Ukrainian Migration to the European Union. Cham (Springer Open). DOI: https://doi.org/ 10.1007/978-3-319-41776-9_7. 
CANGIANO, A. 2014: Migration Policies and Migrant Employment Outcomes. Comparative Migration Studies 2(4), 417-443. DOI: https://doi.org/10.5117/CMS2014.4.CANG.

CAVALLINI, S., SOLDI, R., DI MATTEO, L., UTMA, A. M., ERRICO, B. 2018: Addressing brain drain: The local and regional dimension. Brussels (European Committee of the Regions).

CERNA, L. 2016: The crisis as an opportunity for change? High-skilled immigration policies across Europe. Journal of Ethnic and Migration Studies 42(10), 1610-1630. DOI: https://doi.org/10.1080/1369183X.2016.1162355.

CHUDŽÍKOVÁ, A., BARGEROVÁ, Z. 2018: Victims of labour exploitation or "illegal" migrants? Ukrainian workers' labour rights protection in Slovakia. Bratislava (Centre for the Research of Ethnicity and Culture CVEK). Retrieved from: http://cvek.sk/wp-content/uploads/2018/02/WEB_EN.pdf.

DIVINSKÝ, B. 2007: Náčrt fundamentálnych trendov v zahraničnej migrácii Slovenskej republiky a identifikácia klúčových výziev. Forum Statisticum Slovacum, 3, 57-63.

DOLÁKOVÁ, D. 2016: Migrácia medzi Východným Slovenskom a Velkou Britániou - diplomová práca. Košice (Prírodovedecká fakulta UPJŠ, Ústav geografie).

EICHHORST, W. et al., 2017: People to Jobs, Jobs to People: Global Mobility and Labor Migration. IZA Research Report No. 74, Bonn (IZA).

ERÖSS, Á, KOVÁLY, K, TÁTRAI, P. 2016: Effects of the Ukrainian Crisis in Transcarpathia: the Hungarian Perspective. CMR working papers 92/150. Retrieved from: https://depot.ceon.pl/bitstream/handle/123456789/11158/WP92150.pdf?sequence=1\&isAllowed=y.

EURABOTA 2019a: Job offers for Ukrainians in the EU (website) [cit. 2019-07-31]. Retrieved from: https://www.eurabota.ua/ua.

EURABOTA 2019b: Job offers for Ukrainians in Slovakia (website) [cit. 2019-07-31]. Retrieved from: https://www.eurabota.ua/ua/jobs-in/slovakia/jobs-offered.

EUROSTAT 2020a: GDP per capita in PPS, Index (EU27_2020 = 100). Luxembourg (Eurostat). Retrieved from: https://ec.europa.eu/eurostat/databrowser/product/view/TEC00114?lang=en.

EUROSTAT 2020b: Regional gross domestic product (PPS per inhabitant in \% of the EU27 average) by NUTS 2. Luxembourg (Eurostat). Retrieved from: https://ec.europa.eu/eurostat/databrowser/product/view/TGS00006?lang=en.

EUROSTAT 2020c: Regional gross domestic product (PPS per inhabitant) by NUTS 2 regions. Luxembourg (Eurostat). Retrieved from: https://ec.europa.eu/eurostat/databrowser/product/view/TGS00005?lang=en.

EUROSTAT 2020d: Population change - Demographic balance and crude rates at regional level (NUTS 3). Luxembourg (Eurostat). Retrieved from: https://appsso.eurostat.ec.europa.eu/nui/submitViewTableAction.do.

EUROSTAT 2019: First residence permits issued in the EU Member States. Luxembourg (Eurostat). Retrieved from: https://ec.europa.eu/eurostat/documents/2995521/10189082/325102019-AP-EN.pdf/95e08bc8-476d-1f7d-a519-300bdec438cb.

EUROSTAT 2018a: First residence permits issued in the EU Member States. Luxembourg (Eurostat). Retrieved from: https://ec.europa.eu/eurostat/documents/2995521/9333446/325102018-AP-EN.pdf/3fa5fa53-e076-4a5f-8bb5-a8075f639167.

EUROSTAT 2018b: Migration and migrant population statistics. Luxembourg (Eurostat). Retrieved from: https://ec.europa.eu/eurostat/statistics-explained/index.php/Migration_and_migrant_population_statistics.

EUROSTAT 2017: First residence permits issued in the EU Member States. Luxembourg (Eurostat). Retrieved from: https://ec.europa.eu/eurostat/documents/2995521/8456381/316112017-BP-EN.pdf/e690a572-02d2-4530-a416-ab84a7fcbf22.

EUROSTAT 2016: First residence permits issued in the EU Member States. Luxembourg (Eurostat). Retrieved from: https://ec.europa.eu/eurostat/documents/2995521/7715617/327102016-BP-EN.pdf/ca706fa0-14fc-4b71-a2e2-46b2b933f8f8.

EUROSTAT 2015: First residence permits issued in the EU Member States. Luxembourg (Eurostat). Retrieved from: https://ec.europa.eu/eurostat/documents/2995521/7038745/320102015-BP-EN.pdf/70063124-c3f2-4dfa-96d5-aa5044b927a6. 
EUROSTAT 2014: Residence permits for non-EU citizens in the EU28. Luxembourg (Eurostat). Retrieved https://ec.europa.eu/commission/presscorner/detail/en/STAT_14_159.

FEDYUK, O., KINDLER, M. eds. 2016: Ukrainian Migration to the European Union. Lessons from Migration Studies, ed. Cham (Springer Open).

FONSECA, M. L., PEREIRA, S., ESTEVES, A. 2014: Migration of Ukrainian nationals to Portugal: Changing flows and the critical role of social networks. Central and Eastern European Migration Review, 3, 115-130.

GÓRNY, A. 2017: All circular but different: Variation in patterns of Ukraine to Poland migration. Population, Space and Place, 23(8), e2074. DOI: https://doi.org/10.1002/psp.2074.

GRANČAY, M., GRANČAY, N. 2017: Foreign Direct Investment in Slovakia: The Tatra Tiger Gone Tame? In Szent-Iványi B. ed. Foreign Direct Investment in Central and Eastern Europe. Studies in Economic Transition. Cham (Palgrave Macmillan), pp. 77-98. DOI: https://doi.org/10.1007/978-3-319-40496-7_4.

GREEN, F., ZHU, Y. 2010: Over-qualification, job dissatisfaction, and increasing dispersion in the returns to graduate education. Oxford Economic Papers, 62(4), 740-763. DOI: https://doi.org/10.1093/oep/gpq002.

GULINA, O., POZNIAK, O. 2018: Migration flows from Ukraine: changing trends. ZOiS Spotlight 13/2018. Retrieved from: https://en.zois-berlin.de/publications/zois-spotlight2018/migration-flows-from-ukraine-changing-trends/.

HALÁS, M. 2008: Priestorová polarizácia spoločnosti s detailným pohl'adom na periférne regióny Slovenska. Sociologický časopis (Czech Sociological Review), 44, 349-369.

HALÂS, M. 2014: Modelovanie priestorového usporiadania a dichotómie centrum-periféria. Geografie, 119, 384-405.

HOMOLA, M. 2019: Odliv mozgov sa znižuje. Omrzelo Slovákov zahraničie? Trend.sk. Retrieved from: https://www.trend.sk/spravy/odliv-mozgov-znizuje-omrzelo-slovakov-zahranicie.

IGLICKA, K., WEINAR, A. 2008: Ukrainian Migration in Poland from the Perspective of Polish Policies and Systems' Theory. Journal of Immigrant \& Refugee Studies, 6(3), 356-365.

IOM 2020: Key Migration and Integration Terms. Bratislava (IOM - International Organization for Migration - Slovak Republic). Retrieved from: https://www.iom.sk/en/press-room/keymigration-terms.html.

JANKO, M. 2019: Brexit už vyhnal pätinu Slovákov. Trend.sk. Retrieved from: https://www.trend.sk/trend-archiv/brexit-vyhnal-patinu-slovakov.

JAROSZEWICZ, M. 2018: Migration from Ukraine to Poland - the trend stabilizes. OSW report of Center of Eastern Studies. Warsaw (Centre for Eastern Studies). Retrieved from: https://www.osw.waw.pl/sites/default/files/Report_Migration\%20from\%20Ukraine_net.pdf.

KACZMARCZYK, P. 2015: Burden or Relief? Fiscal Impacts of Recent Ukrainian Migration to Poland, IZA DP No. 8779. Bonn (Institute for the Study of Labor - IZA). Retrieved from: https://pdfs.semanticscholar.org/3e93/4a8b4edfe0f2d3d3d5382d3c5d62659dc727.pdf.

KINCSES, A. 2015: International Migration Diversity in Hungary in the 2011 Population Census Data. Regional Statistics 5(2), 108-124. DOI: https://doi.org/10.15196/TS05206.

KUZIO, M. 2012: Modern Ukrainian immigration to Spain. In Sushko, I. et al. eds. UkraineSpain migration nexus. Ukraine's input to migration map of Europe on the example of Spain. Kiev (Europe without Barriers), pp. 37-64. Retrieved from: https://www.irf.ua/files/ ukr/programs/euro/spain-ukraine_eng.pdf.

LIBANOVA, E. 2019: Labour migration from ukraine: key features, drivers and impact. Economics \& Sociology, 12(1), 313-328. DOI: https://doi.org/10.14254/2071-789X.2019/12-1/19.

LIPTÁKOVÁ, J. 2010: Tackling the crisis. The Slovak Spectator. Retrieved from: https://spectator.sme.sk/c/20038368/tackling-the-crisis.html.

MALYNOVSKA, O. ed. 2016: Migration in Ukraine: facts and figures. Kiev (IOM Mission in Ukraine). Retrieved from: http://iom.org.ua/sites/default/files/ff_eng_10_10_press.pdf.

MIAS 2009-2020: Statistical Overview of Legal and Illegal Migration in the Slovak Republic (Yearbooks for 2008-2019). Bratislava (MIAS - Ministry of Internal Affairs of Slovakia; Presidium of the Police Force - Bureau of Border and Foreigners Police). Retrieved from: https://www.minv.sk/?rocenky. 
MILSAF 2020: Spatial mobility of foreigners - basic terminology. Bratislava (MILSAF - Ministry of Labour, Social Affairs and Family of the Slovak Republic). Retrieved from: https://www.employment.gov.sk/sk/informacie-cudzincov/zakladne-pojmy/.

MISHCHUK, H., ROSHCHYK, I., SUŁKOWSKA, J., VOJTOVIC, S. 2019: Prospects of assessing the impact of external student migration on restoring country's intellectual potential (the case study of Ukraine). Economics and Sociology, 12(3), 209-219. DOI: https://doi.org/ 10.14254/2071-789X.2019/12-3/14.

MUKOMEL, V. 2017: Migration of Ukrainians to Russia in 2014-2015. E-International Relations, 1-8. Retrieved from: https://www.e-ir.info/pdf/68744.

NEJEDLÝ, T. 2019: Zahraničných študentov pribúda. Univerzity aktívne oslovujú mladých na Ukrajine či v Srbsku. Trend.sk. Retrieved from: https://www.trend.sk/trend-archiv/zahranicnych-studentov-pribuda-univerzity-aktivne-oslovuju-mladych-ukrajine-srbsku.

NIKOLOVA, M. 2015: Ukrainian migration to Greece: Patterns and challenges of remaining and of return. Central and Eastern European Migration Review, 4, 107-120.

NOVOTNÝ, L. 2019: Impact of Migration on Rural Regions in Post-socialist Slovakia. In Bański, J. ed. Three Decades of Transformation in the East-Central European Countryside. Cham (Springer), 165-189. DOI: https://doi.org/10.1007/978-3-030-21237-7.

NOVOTNÝ, L., PREGI, L., KMEC, M. 2018: Regionálny subsystém východného Slovenska v modeli diferenciálnej urbanizácie. In Kulla, M., Novotný, L., Onačillová, K. eds. Zborník abstraktov z 8. medzinárodného geografického kolokvia v Danišovciach. Košice (UPJŠ), p. 24.

NOWOTNY, K. 2016: Are Overqualified Migrants Self-Selected? Evidence from Central and Eastern European Countries. Journal of Human Capital, 10, 303-346. DOI: https://doi.org/ $10.1086 / 687415$.

OLSAF 2020: Employment of foreigners in the Slovak Republic in 2020 (February). Statistics on employment of foreigners. Bratislava (Central Office of Labour, Social Affairs and Family) Retrieved from: https://www.upsvr.gov.sk/statistiky/zamestnavanie-cudzincov-statistiky/kopiazamestnavanie-cudzincov-na-uzemi-slovenskej-republiky-za-rok-2019.html?page_id=973500.

PREGI, L., NOVOTNÝ, L. 2019: Selective migration of population in functional urban regions of Slovakia. Journal of Maps, 15, 94-102. DOI: https://doi.org/10.1080/17445647. 2019.1661880.

ONUFRÁK, A., KLIMOVSKÁ, Z., DZURDŽENÍK, J., HUMENNA, O., GUZINETSET, Y. 2017: Migration in the Regions of Eastern Slovakia and Zakarpattya Region of Ukraine, Slovakia - Ukraine: Cooperation Across the Border, DOI: https://doi.org/10.13140/ RG.2.2.23442.76486.

SEMCHUK, K. 2020: The pandemic has returned migrant workers to Ukraine. OpenDemocracy.net. Retrieved from: https://www.opendemocracy.net/en/odr/pandemic-has-returnedmigrant-workers-ukraine-will-they-stay/.

SERT, D. S. 2016: From skill translation to devaluation: the de-qualification of migrants in Turkey. New Perspectives on Turkey, 54, 97-117.

SOKOŁOWICZ, M., LISHCHYNSKYY, I. 2018: Are Poland and Ukraine Gravity Centres for Each Other? Study on the Labour Migration Patterns. Comparative Economic Research 21(1), 45-65. DOI: https://doi.org/10.2478/cer-2018-0003.

SOSR 2019a: Anonymised data on individual cross-border migrations 1996-2018. Bratislava (SOSR - Statistical office of the Slovak Republic).

SOSR 2019b: StatDat - Earnings of employees by NACE Rev. 2. Bratislava (SOSR - Statistical office of the Slovak Republic).

SOSR 2020a: Datacube - 1.6 Income and living conditions of households. Bratislava (SOSR - Statistical office of the Slovak Republic).

SOSR 2020b: Datacube - Registered unemployment rate. Bratislava (SOSR - Statistical office of the Slovak Republic).

ŠTEFÁNIK, M. et al., 2018: Labour market in Slovakia 2019+. Bratislava (Prognostický Ústav SAV). Retrieved from: http://www.prog.sav.sk/labour-market-slovakia-2019.

STRIELKOWSKI, W., GRYSHOVA, I. 2016: Ukrainian labour migration on the Czech Republic. Scientific bulletin of Polissia, 4(8), 224-231. 
SSSU 2018: Migration of population 2018 by region. Kiev (SSSU - State Statistic Service of Ukraine). Retrieved from: http://www.ukrstat.gov.ua/operativ/operativ2018/ds/mr/mr_e/ mr1218_e.html.

ŠVECOVÁ, A., RAJČÁKOVÁ, E., 2013: Unemployment in Slovak Republic in the Context of Regional Disparities in 2001-2011. Geographia Cassoviensis, 7(1), 147-156.

TREVENA, P. 2013: Why do highly educated migrants go for low-skilled jobs? A case study of Polish graduates working in London. In: Glorius, B., Grabowska-Lusinska, I., Kuvik, A., eds. Mobility in Transition: Migration Patterns after EU Enlargement. Amesterdam (Amesterdam University), pp. 170-191.

TYSHCHUK, T. 2018: The Great Migration: No One in Ukraine Knows How Many of Our Compatriots Have Moved Abroad. VoxUkraine.org. Retrieved from: https://voxukraine.org/en/thegreat-migration-no-one-in-ukraine-knows-how-many-of-our-compatriots-have-moved-abroad/.

UN 2020: UN Global Issues - Migration. New York (UN - United Nations). Retrieved from: https://www.un.org/en/sections/issues-depth/migration/.

UNIM 2019: International migrant stock 2019: Country Profiles. United Nations - Population Division - International Migration. New York (United Nations). Retrieved from: https:// www.un.org/en/development/desa/population/migration/data/estimates2/countryprofiles.asp.

VALENTA, O., DRBOHLAV, D. 2018: Longitudinal and spatial perspectives on the mismatch of tertiary educated migrant workers in the Czech labour market: The case of Ukrainians, Moravian Geographical Reports, 26(4), 255-272. DOI: https://doi.org/ 10.2478/mgr-2018-0021.

VAN MOL, CH., SNEL, E., HEMMERECHTS, K., TIMMERMAN, CH. 2018: Migration aspirations and migration cultures: A case study of Ukrainian migration towards the European Union. Population Space and Place, 24:e2131, 1-11. DOI: https://doi.org/10.1002/psp.2131.

VIANELLO, F. A., 2014: Ukrainian migrant workers in Italy: Coping with and reacting to downward mobility. Central and Eastern European Migration Review, 3, 85-98.

WORLD BANK 2020: Extract from World Development Indicators. Washington D.C. (Wold Bank). Retrieved from: https://databank.worldbank.org/reports.aspx?source=2\&series= NY.GDP.PCAP.PP.CD\#.

Acknowledgement: $R$. Koroutchev warmly thanks the research fellowship from SAIA, Slovakia, which made this publication possible. He also thanks the Institute of Geography of the Faculty of Science, the Pavol Jozef Šafárik University in Košice, Slovakia, for the kind hospitality during the research stay.

\author{
Authors' affiliations \\ Dr. Rossen Koroutchev, PhD \\ Group of Mediterranean Studies, Dep. Arab, Islamic and Oriental Studies \\ Faculty of Arts and Philosophy, Universidad Autónoma de Madrid \\ 28049 Cantoblanco, Madrid \\ Spain \\ rkoroutchev@yahoo.es \\ Mgr. Ladislav Novotný, PhD. \\ Institute of Geography \\ Faculty of Science, Pavol Jozef Šafárik University in Košice \\ Jesenná 5, 04001 Košice \\ Slovakia \\ ladislav.novotny@upjs.sk
}

